\title{
Comparative effects of dietary nucleoside- nucleotide mixture and its components on endotoxin induced bacterial translocation and small intestinal injury in protein deficient mice
}

\author{
A A Adjei, K Yamauchi, Y C Chan, M Konishi, S Yamamoto
}

\begin{abstract}
Background-Nucleoside-nucleotide mixture has been shown to improve gut morphology and reduce the incidence of bacterial translocation in protein deficient mice.

Aims-To compare the reparative effect of nucleoside-nucleotide mixture and their individual components on maintenance of gut integrity and bacterial translocation based on their differential metabolism and utilisation.

Methods-ICR (CD-1) mice were randomised into eight groups of 10 animals each and fed $20 \%$ casein diet (control), protein free diet, or protein free diet supplemented with $3 \mathrm{M}$ cytidine, uridine, thymidine, inosine, guanosine monophosphate, or nucleoside-nucleotide mixture for four weeks. On the fourth week, each mouse was injected lipopolysaccharide intraperitoneally $(50 \mu \mathrm{g} / 500 \mu \mathrm{l})$ and the incidence of bacterial translocation, caecal bacterial populations, and the ileal histology, noted 48 hours later.
\end{abstract}

Results-The death rate in the control group was $40 \%$ compared with $10 \%$ in the nucleoside-nucleotide mixture and $20 \%$ each in the individual components groups, respectively. Bacterial translocation to the mesenteric lymph node did occur in $100 \%$ of the surviving mice fed the control diet in comparison with 44\% (nucleoside-nucleotide), 50\% (cytidine), $75 \%$ (thymidine), $75 \%$ (uridine), $63 \%$ (inosine), and 63\% (guanosine monophosphate). Histologically, the damage to the gut was more distinct in the protein free diet group. Villous height, crypt depth, and wall thickness in the nucleoside-nucleotide mixture group mean (SEM) $(5.01(0.34) ; 0.87(0.14) ; 0.33$ $(0 \cdot 10))$, were respectively, higher compared with the protein free diet $(3.34$ $(0.34) ; 0.61(0.03) ; 0.18(0.04))$ group. In the cytidine group, crypt depth $(0 \cdot 86)$ $(0.08))$, and wall thickness $(0.30(0.002))$ were higher. The same measurements in the components groups tended to be higher than the protein free diet group. Caecal bacterial populations were, however, similar in all groups.

Conclusions-These results suggest that dietary nucleosides and nucleotides are essential nutrients for intestinal repair; and that a mixture of nucleosides and nucleotides or cytidine provide a better response.

(Gut 1996; 38: 531-537)

Keywords: nucleosides, nucleotides, bacterial translocation, protein deficiency, endotoxin.

The gastrointestinal tract plays a primary part in the digestion and absorption of nutrients, but it is also essential as a barrier to enteric flora, preventing host invasion by micro-organisms or bacterial endotoxins. ${ }^{12}$ Nevertheless, recent data suggest that under certain clinical and experimental conditions, this intestinal barrier function seems to be impaired leading to the translocation of bacteria or endotoxin to the mesenteric lymph nodes, spleen, liver, and bloodstream, initiating the septic process that perpetrates multiple organ failure. ${ }^{3}$ Some commercially available parenteral (Aminosyn) and enteral formulas (Osmolite) used for nutritional treatment of critically ill or immunocompromised patients fail to support gut mucosal structure or function. This occurs because the formulas do not contain glutamine, fibre, or nucleic acid components, which are required for normal enterocyte growth or repair after an insult and during periods of critical illness. ${ }^{4}$

There are a number of factors that participate in the modulation of the renewal of the absorptive epithelium and in the repair of the gut under abnormal conditions. ${ }^{5}$ Nitrogen containing substrates seem to be of great importance for gut development. Dietary nucleotides have been described as improving growth in weanling rats fed a low protein diet, ${ }^{6}$ and as stimulating the in vitro and in vivo growth of intestinal bifidobacteria. ${ }^{78}$ Oral supplementation of total parenteral nutrition with nucleoside-nucleotide mixture prevented the intestinal mucosal atrophic changes in the ileum of rats induced by total parenteral nutrition. ${ }^{9}$ Nucleoside supplementation increased the rate of maturation and growth in the young rat, as determined by mass, RNA, DNA, and protein concentrations and activity of brush border enzymes. ${ }^{10}$ Nucleotide supplementation restored the biochemical indices of the small intestine at proximal and distal sites, and improved intestinal changes after induction of chronic diarrhoea. ${ }^{11-14}$ Dietary nucleotides are also implicated in the maintenance of the immune response. ${ }^{15} 16$ Intraperitoneal or oral 
administration of nucleoside-nucleotide mixture improved gut morphology and reduced the incidence of bacterial translocation in protein deficient mice. ${ }^{1718}$ These substrates have been studied in normal humans under stress, and animal models. ${ }^{11-1419}$ Whereas much attention have been focused on the use of combinations of nucleosides, nucleotides or nucleic acids in the improvement of gut integrity and function, one question that has not been considered conclusively is which components of nucleic acids, nucleotides, nucleosides are effective. This question is of clinical significance because of the differential metabolism and utilisation of individual nucleotides and nucleosides, as evidenced by some investigators. ${ }^{20-22}$ To answer this question, this study was designed to see the effect(s) of dietary nucleosides and nucleotides on the incidence of endotoxin induced bacterial translocation, intestinal bacterial populations, and morphology of the gut in protein deficient mice and to evaluate the relative importance of nucleosides and nucleotides. We used protein deficient mice because protein deficiency is the most common cause of immunosuppression worldwide, ${ }^{23}$ and, in combination with endotoxin, results in deficiency of the gut and potentiates bacterial translocation. ${ }^{24}$

\section{Methods}

\section{Animals}

Specific pathogen free ICR (CD-1) mice were obtained from Kyudo Breeding Laboratories (Kumamoto, Japan) and used for the experiment. Weight matched $(29 \pm 2$ g) 8 week old female mice were kept in a constant temperature $\left(25 \pm 2^{\circ} \mathrm{C}\right)$ and humidity $(50-70 \%)$ room with a 12 hour light period from 0800 to 2000. Animal care was in compliance with applicable guidelines from the Ryukyus University Policy on Animal Care and Use. The mice were kept for one week before the onset of the experiment to acclimatise to our laboratory conditions. During this period the mice received normal non-purified diet (Nihon Clear, Osaka, Japan). This standard mouse diet contains $25.5 \%$ protein and $4.3 \%$ fat by weight.

Study protocol

After the period of acclimatisation, the mice were randomised into eight groups according to the dietary treatment. Each diet was started four weeks before the administration of endotoxin, and was continued until the mice were killed. On the fourth week on the diet, mice were intraperitoneally given lipopolysaccharide $(50 \mu \mathrm{g} / 500 \mu \mathrm{l})$ and killed by cervical dislocation 48 hours later, and the incidence of bacterial translocation, caecal bacterial populations, and the damage to the intestine were investigated.

\section{Endotoxin}

Lipopolysaccharide (from Escherichia coli 026:B6, Wako Chemical, Tokyo, Japan) was dissolved in pyrogen free saline to a final concentration of $50 \mu \mathrm{g} / 500 \mu \mathrm{l} ; 500 \mu \mathrm{l}$ was injected intraperitoneally into each animal used for the experiment. We used $50 \mu \mathrm{g}$ lipopolysaccharide because previous results showed that this dose and timing did not cause death, yet resulted in bacterial translocation in $100 \%$ of the injected mice. ${ }^{1718}$ Lipopolysaccharide was used because it has been shown that protein malnutrition alone does not induce translocation. $^{24}$

Diet

The control mice were fed $20 \%$ casein diet (nucleic acid free), and the remaining groups of mice were fed protein free diet, or protein free diet supplemented with $3 \mathrm{M}$ guanosine monophosphate (guanosine group), inosine (inosine group) (purines), cytidine (cytidine group), uridine (uridine group), thymidine (thymidine group) (pyrimidines), or a nucleoside-nucleotide mixture (nucleosides-nucleotide group) per $\mathrm{kg}$ diet throughout the investigation. The mixture (Otsuka Pharmaceutical Factory, Tokushima, Japan) was developed to compensate for a decrease in the intrinsic pools of purines and pyrimidines because of the increased enzyme activity in salvage under various abnormal conditions. ${ }^{25}$ It consisted of inosine $(8 \mathrm{~g} / \mathrm{l})$, guanosine monophosphate $(12.2 \mathrm{~g} / \mathrm{l})$, cytidine $(7.3 \mathrm{~g} / \mathrm{l})$, uridine $(5.5 \mathrm{~g} / \mathrm{l})$, and thymidine $(1.8 \mathrm{~g} / \mathrm{l})$ at a molar ratio of $4: 4: 4: 3: 1$. The diets were made isonitrogenous and isocaloric by adding an appropriate amount of glycine. Table I shows the composition of the diets. The nucleotide content of the control diet and protein free diet was negligible as determined by high

TABLE I Composition of experimental diets (g/kg)

\begin{tabular}{|c|c|c|c|c|c|c|c|c|}
\hline & Control & $\begin{array}{l}\text { Protein } \\
\text { free diet }\end{array}$ & $\begin{array}{l}\text { Nucleoside- } \\
\text { nucleotide }\end{array}$ & Uridine & Thymidine & Cytidine & Inosine & $\begin{array}{l}\text { Guanosine } \\
\text { monophosphate }\end{array}$ \\
\hline Casein & 200 & 0 & 0 & 0 & 0 & 0 & 0 & 0 \\
\hline Glycine & $9 \cdot 6$ & $9 \cdot 6$ & 0 & 0 & 0 & 0 & 0 & 0 \\
\hline Nucleic acid & 0 & 0 & $6 \cdot 5$ & $5 \cdot 5$ & $5 \cdot 5$ & $5 \cdot 5$ & $6 \cdot 0$ & $9 \cdot 2$ \\
\hline Carbohydrate* & 670 & $860 \cdot 4$ & $863 \cdot 5$ & $864 \cdot 5$ & $864 \cdot 5$ & $864 \cdot 5$ & 864 & $860 \cdot 8$ \\
\hline Corn oil & 50 & 50 & 50 & 50 & 50 & 50 & 50 & 50 \\
\hline Mineral mixture† & 50 & 50 & 50 & 50 & 50 & 50 & 50 & 50 \\
\hline Vitamin mixture & 10 & 10 & 10 & 10 & 10 & 10 & 10 & 10 \\
\hline Cellulose & 20 & 20 & 20 & 20 & 20 & 20 & 20 & 20 \\
\hline
\end{tabular}

${ }^{\star} \alpha$-corn starch:sucrose, $2: 1$ ratio.

†Obtained from Oriental Yeast, Tokyo. The composition was: $(\mathrm{mg} / \mathrm{kg}) \mathrm{CaHPO}_{4} 2 \mathrm{H}_{2} \mathrm{O}, 7280 ; \mathrm{KH}_{2} \mathrm{PO}_{4}, 12860 ; \mathrm{NaH}_{2} \mathrm{PO}_{4}, 4680$; $\mathrm{NaCl}, 2330$; Ca lactate, $17550 ; \mathrm{Fe}$ citrate, $1590 ; \mathrm{MgSO}_{4}, 3590 ; \mathrm{ZnCO}_{3}, 55 ; \mathrm{MnSO}_{4} 4-6 \mathrm{H}_{2} \mathrm{O}, 60 ; \mathrm{CuSO}_{4} 5 \mathrm{H}_{2} \mathrm{O}, 15 ; \mathrm{KI}_{4}$. †Obtained from Oriental Yeast, Tokyo. The composition was: $(\mathrm{mg} / \mathrm{kg})$ thiamin $\mathrm{HCl}, 12$; riboflavin, 40 ; pyridoxine $\mathrm{HCl}, 8$;

vitamin B-12, 50; ascorbic acid, 300; D-biotin, 0.2; folic acid, 2; calcium pantothenate, 50; $\rho$-aminobenzoic acid, 50 ; niacin, 60 ; inositol, 60; choline chloride, 2000; dl- $\alpha$ tocopheryl acetate, 50; menadione, 52; and retinyl acetate, 5000; ergocalciferol, 1000. 
performance liquid chromatography. Animals in all the groups were given free access to the food and water. From 10 to 11 am every morning, the animals were weighed and food and water renewed.

\section{Bacterial translocation}

The mice were killed by cervical dislocation and the abdomen was shaved and cleaned with isodine. The skin and the peritoneum of the abdomen were opened with sterile instruments, and the exposed viscera were swabbed with cotton tipped applicator sticks, which were cultured in brain heart infusion broth (Wako Chemical, Tokyo, Japan) to detect any accidental bacterial translocation. The mesenteric lymph node, spleen, liver, and caecum were aseptically removed, and each was placed in tubes containing $3 \mathrm{ml}$ of sterile brain heart infusion broth. The organs were homogenised with Teflon grinders. After preparations of 10 -fold serial dilutions, $100 \mu \mathrm{l}$ aliquots of the homogenate were placed onto polymyxin B nalidixic acid agar plate for the detection of aerobic and facultative Gram positive bacteria, and onto MacConkey's agar plates (Wako Chemical, Tokyo, Japan) for the detection of aerobic and facultative Gram negative bacteria. The plates were incubated at $37^{\circ} \mathrm{C}$ for 24 hours; and the bacteria were counted as the viable $\log _{10}$ per tissue. Tissues were considered to be 'positive' if greater than 100 colony forming units per tissue were found. Representative colonies on both agar plates were identified by using standard microbiological procedures.

Tissue processing for light microscopic analysis The animals were weighed and killed between 10 and 11 am because the small intestine shows circadian differences in morphology and activity. The small intestine from the pylorus to the ileocaecal valve was removed and divided into two equal segments; the proximal and the terminal parts. The intestinal lumen of the terminal part was perfused with isotonic buffered saline solution $(\mathrm{NaCl} 120 \mathrm{mM}, \mathrm{KCl}$ $5 \mathrm{mM}$, and $\mathrm{NaHCO}_{3} 23 \mathrm{mM}$ ) for two minutes to remove debris. Samples of terminal ileum in each dietary group were fixed in $37-40 \%$ phosphate buffered formalin (37-40\% formaldehyde $10 \mathrm{ml}$; sodium phosphate monobasic $1.86 \mathrm{~g}$; sodium hydroxide $0.42 \mathrm{~g}$; distilled water $90 \mathrm{ml}$ )

TABLE II Effect of $20 \%$ casein diet (control), protein free diet (PFD), or protein free diet supplemented with guanosine monophosphate (GMP 2Na), inosine, cytidine, thymidine, uridine, nucleoside-nucleotide mixture on the histology of the ileum of mice ${ }^{\star}$

\begin{tabular}{lllll}
\hline Experimental group & Number & $\begin{array}{l}\text { Villous } \\
\text { height }\end{array}$ & $\begin{array}{l}\text { Crypt } \\
\text { depth }\end{array}$ & $\begin{array}{l}\text { Well } \\
\text { thickness }\end{array}$ \\
\hline Control & 10 & $6.78(0.39) \dagger$ & $0.92(0.10) \dagger$ & $0.40(0.08) \dagger$ \\
PFD & 10 & $3.34(0.34)$ & $0.61(0.03)$ & $0.18(0.04)$ \\
PFD+guanosine monophosphate & 10 & $4.39(0.55)$ & $0.78(0.15)$ & $0.26(0.04)$ \\
PFD+inosine & 10 & $4.37(0.31)$ & $0.77(0.18)$ & $0.26(0.08)$ \\
PFD+cytidine & 10 & $4.56(0.22)$ & $0.86(0.08) \dagger$ & $0.30(0.02) \dagger$ \\
PFD+thymidine & 10 & $4 \cdot 48(0.74)$ & $0.90(0.15) \dagger$ & $0.25(0.03)$ \\
PFD+uridine & 10 & $4.03(0.68)$ & $0.72(0.07)$ & $0.25(0.08)$ \\
PFD+ nucleoside-nucleotide mixture & 10 & $5.01(0.34)$ & $0.87(0.14)$ & $0.33(0.10) \dagger$ \\
\hline
\end{tabular}

*Villous height, crypt depth, and wall thickness were determined by measuring well oriented villi, crypt, and wall thickness per sample. Values are expressed as mean (SEM) in mm $\times 10^{-1}$ + Within a column, the values are significantly different compared with the protein free diet group. at room temperature overnight. The tissues were sliced into $4-6 \mathrm{~mm}$ pieces, perpendicular to the muscularis mucosa, dehydrated in ethanol, embedded in paraffin wax, sectioned, and stained with haematoxylin and eosin. For each specimen at least 10 sections from each segment and mice in the dietary groups were obtained. The sections were examined and photographed with the use of an Olympus microscope (Olympus Kogyo, Tokyo, Japan). The measurements of villous height, crypt depth, and wall thickness were measured in well oriented villi and crypt per segment using a calibrated micrometre.

\section{Statistical analysis}

Statistical analysis of data was performed by the Fisher's exact test or analysis of variance (ANOVA). Duncan's multiple range tests were used to determine significant differences among means for villous height, crypt depth, and well thickness. A p value $<0.05$ was considered significant.

\section{Results}

\section{General findings}

After four weeks, the mice fed protein free and the protein free supplemented dietary groups lost about $35 \%$ of their original body weight, whereas the mice fed $20 \%$ casein (control) showed a slight but gradual increase in body weight. Body weight loss and food intake were similar between the protein free diet group and the groups supplemented with dietary nucleic acid components (data not shown). Mice challenged with lipopolysaccharide intraperitoneally showed systemic signs of stress (lethargy, conjunctivitis, and ruffled hair) within 16 to 24 hours of receiving the endotoxin. No animals died during the period of protein depletion; however, 48 hours after lipopolysaccharide injection, four of the mice in the protein free diet group, two each in the individual components, and one in the nucleoside-nucleotide mixture groups died. No death(s) occurred in the control dietary group.

\section{Histological changes in the terminal ileum of the small intestine}

The combination of protein deficiency and endotoxin led to profound changes in the morphometric analysis of the terminal ileum in the protein free diet group. The villous height, crypt depth, and wall thickness in the protein free diet group were significantly lower than in the control and nucleoside-nucleotide mixture supplemented groups.

In the protein free diet group, the villous height, crypt depth, and wall thickness in the individual components groups tended to be higher. Significant difference $(p<0.05)$ was noted only in the crypt depth and wall thickness in the cytidine group, and crypt depth in the thymidine group (Table II).

Comparing the control and protein free diet 

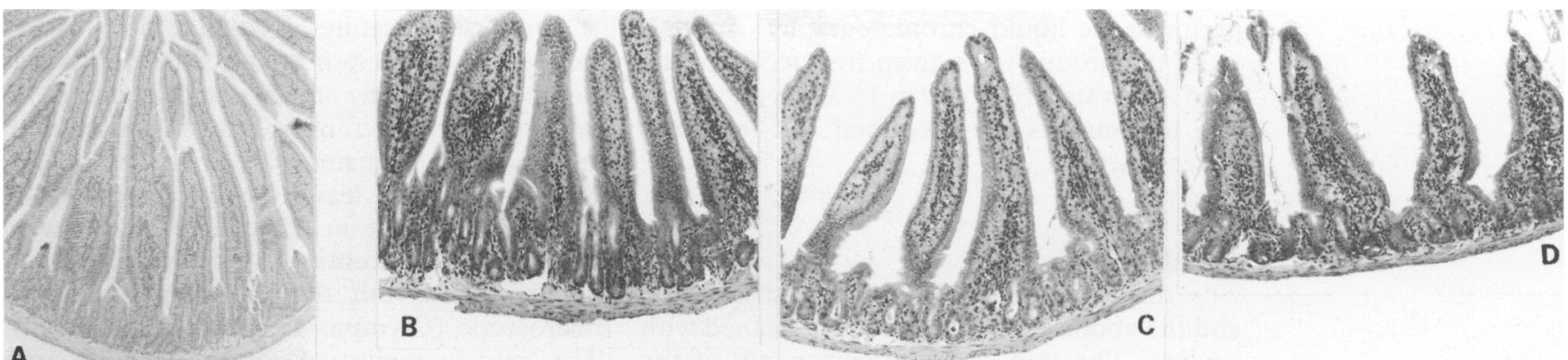

A
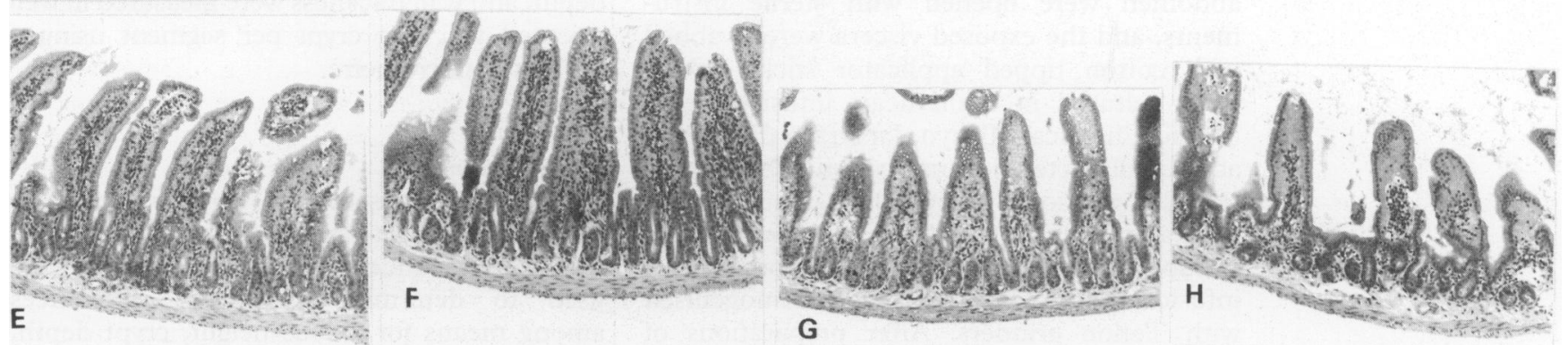

Figure 1: Terminal ileum from a control (20\% casein fed) mouse killed 48 hours after intraperitoneal endotoxin ( $50 \mu g)$ administration, showing normal mucosal architecture $(A, \times 40)$. Terminal ileum from a mouse fed protein free diet supplemented with nucleoside-nucleotide mixture $(B, \times 40)$, or protein free diet supplemented with cytidine $(C, \times 40)$, thymidine $(D, \times 40)$, uridine $(E, \times 40)$, guanosine monophosphate $(F, \times 40)$, inosine $(G, \times 40)$ respectively, and killed 48 hours after intraperitoneal endotoxin $(50 \mu g)$ administration. Trophic changes of the intestinal mucosa and wall are comparable to those shown in $(A)$. The villous height, crypt depth, and wall thickness are well developed and remain intact relative to those shown in $(H)$. Terminal ileum from a mouse fed the protein free diet and killed 48 hours after intraperitoneal endotoxin $(50 \mu \mathrm{g})$ administration. Atrophy of the intestinal mucosa and wall are evident. The villous height and crypt depth are both diminished, with a pronounced decrease in the thickness of the intestinal wall $(H, \times 40)$.

supplemented groups, light microscopy study in the protein free diet group showed pronounced villous atrophy and loss of distinct morphological appearance (Fig 1). The control and supplemented groups showed uniform villi, regular in shape and of the same size.

\section{Incidence of bacterial translocation}

Table III shows the incidence of bacterial translocation in all the dietary groups. The incidences of translocation in the mesenteric lymph node and spleen of the surviving mice in the nucleoside-nucleotide mixture, cytidine dietary groups were lower $(p<0.05)$ than in the protein free diet group. The incidences of translocation were similar among the dietary nucleosides and nucleotides groups. There was no translocation in the control group.

Quantitative colony counts and median numbers of viable aerobic and facultative Gram positive micro-organisms recovered from the mesenteric lymph node of the surviving mice in the nucleoside-nucleotide mixture, guanosine groups were significantly lower $(p<0.05)$ than that of the protein free diet group. The colony counts of micro-organisms recovered from the spleen in the nucleosidenucleotide, uridine, thymidine, and guanosine groups differed significantly $(p<0.05 \%)$ compared with the protein free group (Fig 2A). The colony counts of Gram negative microorganisms in the mesenteric lymph node (nucleoside-nucleotide mixture) and spleens of the nucleoside-nucleotide mixture, uridine, thymidine, cytidine, and guanosine groups were lower $(p<0.05 \%)$ compared with the protein free diet group (Fig 2B). Although supplementation of protein free diet with nucleosides and nucleotides decreased the incidence of bacterial translocation and the number of colony counts of micro-organisms recovered in the mesenteric lymph node and spleen, it did not reduce the number of caecal bacterial populations compared with the protein free diet group (Fig $2 \mathrm{~A}$ and $2 \mathrm{~B}$ ). There was no statistical difference between the combined colony counts of Gram negative and Gram positive micro-organisms recovered from the mesenteric lymph node and spleen of surviving mice in the purine (inosine, guanosine) nucleotides and pyrimidine (thymidine, cytidine, and uridine) nucleosides groups, respectively (Fig $3 \mathrm{~A}$ and $3 \mathrm{~B}$ ).

\section{Discussion}

Since the original description that the small intestine has a limited capacity for de novo synthesis of nucleic acids ${ }^{26}$ coupled with the rapid rate of cellular proliferation and metabolic activity, ${ }^{27}$ many investigators ${ }^{9-12}$ have shown that the absence of nucleotides and nucleosides in the diet may have adverse effects on the gut. We have shown that intraperitoneal and oral administration of nucleosidenucleotide mixture prevented the atrophic changes in the mouse ileum induced by endotoxin in protein deficient mice. ${ }^{17} 18$ In this study, we further extended our investigations on the role of nucleosides and nucleotides on gut integrity and function on the basis of differential metabolism and utilisation of nucleic acids, nucleosides, and nucleotides.

The feeding of protein deficient mice with the individual components and a balanced mixture of the components after challenge with endotoxin resulted in a profound improvement in the ileal histology and a reduced incidence of bacterial translocation. As shown by light microscopy, animals that received protein free diet alone showed 


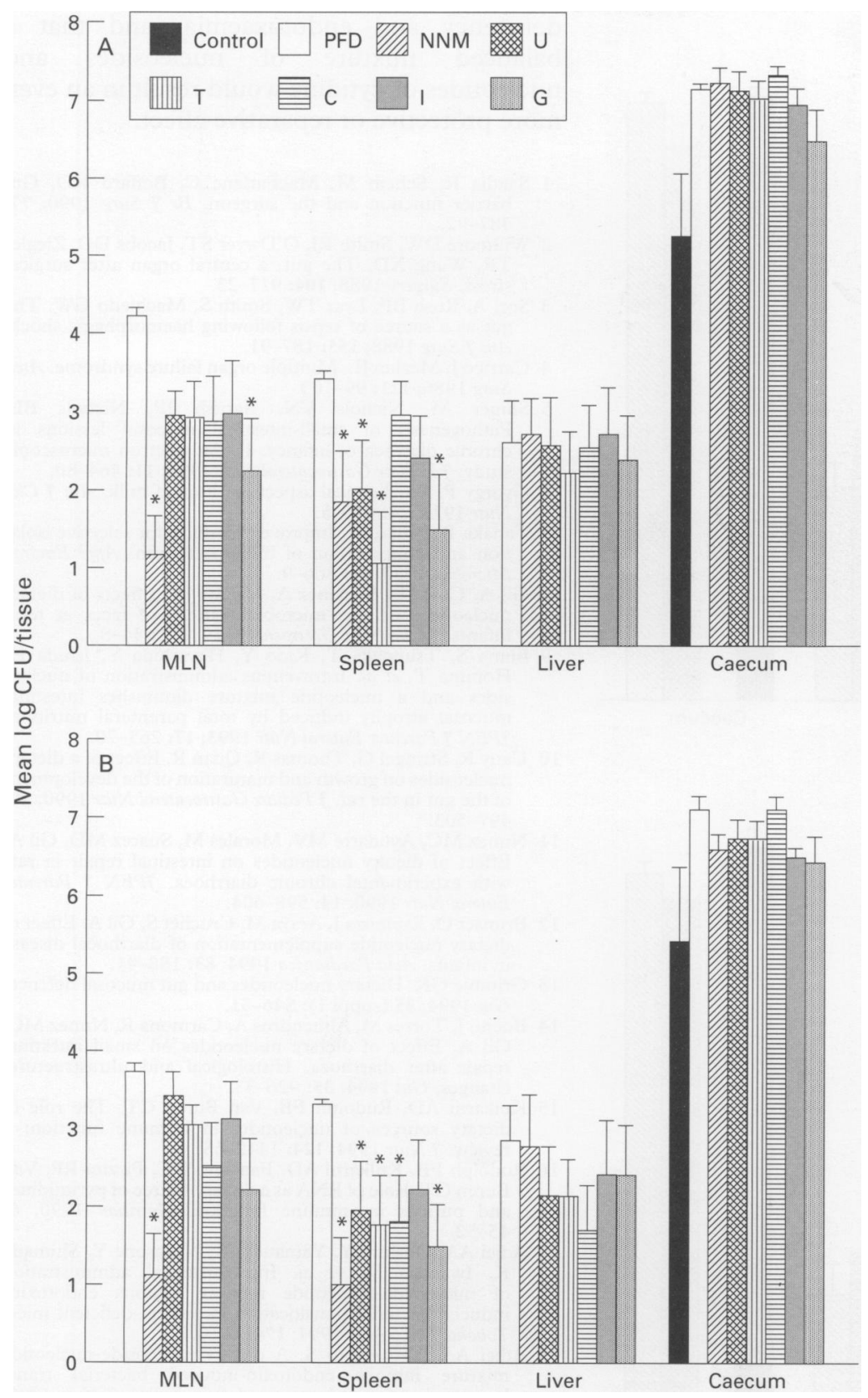

Figure 2: Bacterial translocation of Gram negative (A) and Gram positive (B) micro-organisms to mesenteric lymph node (MLN), spleen, liver, and caecum of surviving mice 48 hours after an intraperitoneal endotoxin administration $(50 \mu \mathrm{g})$. Mice were fed the protein free diet (PFD), or the protein free diet supplemented with nucleoside-nucleotide mixture (NNM), cytidine (C), thymidine $(T)$, uridine $(U)$, guanosine monophosphate $(G)$, and inosine (I), respectively for four weeks. Values are means (SEM); $n=10$ for control, $n=6$ for (PFD), $n=9$ for nucleoside-nucleotide, and $n=8$ for the other supplemented groups, respectively. Significantly higher mean colony forming units (CFU) were recovered in the MLN and spleen from the protein free diet fed group $\left.{ }^{\star} p<0 \cdot 05\right)$.

TABLE III Endotoxin induced bacterial translocation from the gastrointestinal tract of $\operatorname{mice}^{\star}(\%)$

\begin{tabular}{|c|c|c|c|c|c|}
\hline \multirow[b]{2}{*}{ Experimental group } & \multicolumn{5}{|c|}{ Incidence of bacterial translocation $†$} \\
\hline & Number & Mortality & $M L N \ddagger$ & Spleen & Liver \\
\hline Control & 10 & 0 & os & $0 \mathrm{~s}$ & 08 \\
\hline PFD & 6 & 40 & 100 & 100 & 100 \\
\hline PFD+guanosine monophosphate & 8 & 20 & 63 & 63 & 75 \\
\hline PFD+inosine & 8 & 20 & 63 & 63 & 75 \\
\hline PFD + cytidine & 8 & 20 & 505 & 505 & 63 \\
\hline PFD+thymidine & 8 & 20 & 75 & 88 & 75 \\
\hline PFD + uridine & 8 & 20 & 75 & 88 & 75 \\
\hline PFD+ nucleoside-nucleotide mixture & 9 & 10 & $44 \Omega$ & 385 & 63 \\
\hline
\end{tabular}

${ }^{\star}$ Mice were fed $20 \%$ casein diet (control), protein free diet (PFD), or PFD supplemented with $3 \mathrm{M}$ guanosine monophosphate, inosine, cytidine, thymidine, uridine, nucleoside-nucleotide mixture, respectively for four weeks.

tEndotoxin was given intraperitoneally $(50 \mu \mathrm{g})$, and mice were killed 48 hours later. Percentage translocation was determined by dividing the number of mice with bacteria in their respective organs by the total number of animals tested.

¥Translocating bacteria were identified as $E$ coli, $P$ aeruginosa, $M$ morgani, and Enterococcus

species. $M L N=$ mesenteric lymph node.
SWithin a column, the values are significantly different compared with protein free diet group. decreased villous height and wall thickness and shortened crypt depth. Bacterial translocation did occur in all the surviving mice fed protein free diet accompanied with increased colony counts of micro-organisms recovered from the tissues. Animals that received protein free diet supplemented with a balanced mixture of nucleosides and nucleotides or individual components showed increased villous height, crypt depth, and wall thickness resulting in a reduced incidence of bacterial translocation. Furthermore, the nucleosides, nucleotides supplemented dietary groups were less susceptible to the lethal effects of endotoxin compared with the protein free diet group. Caecal bacterial populations were similar among the dietary groups suggesting that dietary nucleosides and nucleotides blocked bacterial translocation by reducing endotoxin induced mucosal or epithelial damage rather than changing caecal bacterial populations of the translocating bacteria. Comparing the protein free diet and individual dietary components groups, our results suggest that nucleosides and nucleotides may improve morphological and functional maintenance or repair during injury, or both; and that the provision of a balanced mixture of nucleotides and nucleosides or cytidine may provide a better response.

Dietary nucleotides are present in foods mainly in the form of nucleoproteins from which the nucleic acids are liberated in the gut as free nucleotides. The nucleotides are metabolised to nucleosides before absorption through different mechanisms, and incorporated into body tissues, mainly the liver, spleen, bone marrow, and the gut. ${ }^{22} 28$ Dietary nucleotides have been shown to serve as precursor units of DNA and RNA in some rapidly growing tissues by the salvage pathway, especially during periods of comparatively low intake of proteins thus sparing the organism from the cost of their de novo synthesis. ${ }^{29} \mathrm{De}$ novo nucleotide synthesis may not be adequate where increased demand for nucleic acid synthesis is induced by the intestinal injury. In such circumstances, the intestine relies on an active salvage pathway of dietary nucleosides to maintain nucleotide pools. Therefore it is quite possible that dietary nucleotides and nucleosides are used more during times of increased need for nucleotides such as when the body is recovering from a significant tissue injury.

Nucleic acid components, purine or pyrimidine nucleosides and nucleotides differ in their metabolism and utilisation. ${ }^{20-22}$ It has been shown that most of the pyrimidines ingested as dietary nucleic acid components were absorbed and quickly catabolised and excreted compared with purines. ${ }^{22}$ Orally administered free pyrimidines were apparently not used by the tissues for nucleic acid synthesis. ${ }^{30-33}$ Supplementation with nucleoside-nucleotide mixture improved nitrogen balance, protein, RNA and DNA synthesis, and was rapidly distributed into the spleen, kidney, liver, bone marrow, intestinal mucosa, and thymus compared with the individual components of the 


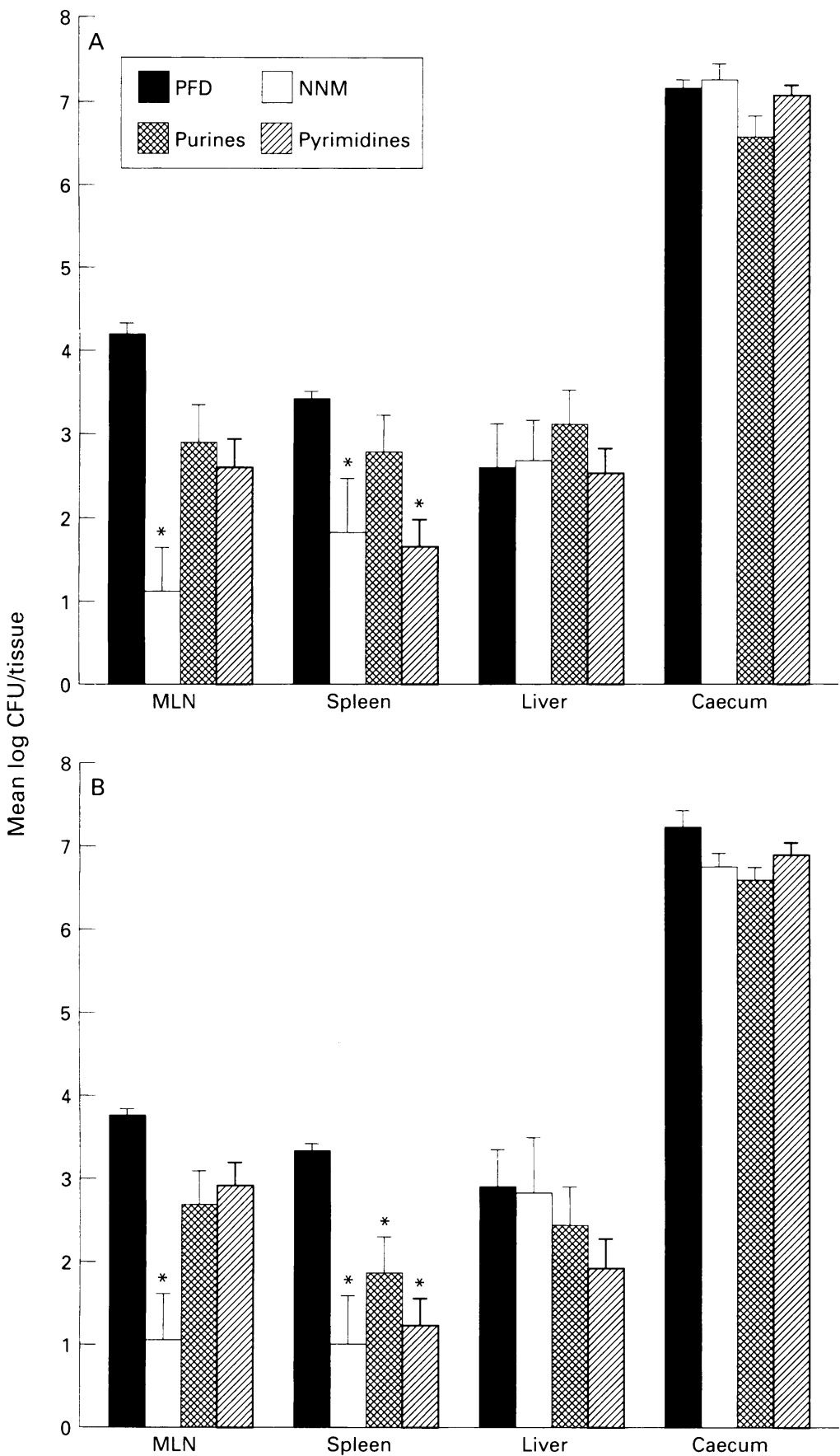

Figure 3: Combined bacterial translocation of Gram negative (A) and Gram positive (B) enterics to mesenteric lymph node $(M L N)$, spleen, liver, and caecum of surviving mice 48 hours after an intraperitoneal endotoxin administration $(50 \mu \mathrm{g})$. Values are means (SEM); $n=6$ for PFD, $n=9$ for nucleoside-nucleotide mixture (NNM), $n=24$ for pyrimidines, $n=16$ for purines. Significantly higher mean colony forming units (CFU) were recovered in the $M L N$ and spleen from the protein free diet fed group $\left({ }^{\star} p<0.005\right)$.

mixture. ${ }^{34} 35$ Our results could not determine the difference(s) between purine nucleotides and pyrimidine nucleosides because there was no significant differences in the ileal histology, caecal bacterial populations, and clearance of translocating micro-organisms. In comparison with the protein free diet group, provision of purine, pyrimidine nucleotides and nucleosides, provided better morphological and functional maintenance or repair of the damaged gut, or both, secondary to protein deficiency and endotoxaemia.

In conclusion, this study supports the concept that dietary purine nucleotides and pyrimidine nucleosides may prevent some of the morphological atrophy secondary to protein deficiency and endotoxaemia; and that a balanced mixture of nucleosides and nucleotides or cytidine would result in an even more protective or reparative effect.

1 Saadia R, Schein M, MacFarlane C, Boffard KD. Gu barrier function and the surgeon. Br F Surg 1990; 77 487-92.

2 Willmore DW, Smith RJ, O'Dwyer ST, Jacobs DO, Ziegler TR, Wang XD. The gut: a central organ after surgical stress. Surgerv 1988; 104: 917-23.

3 Sori A, Rush BF, Lysz TW, Smith S, Machiedo GW. The gut as a source of sepsis following haemorphagic shock. gut as a source of sepsis followir

4 Carrico J, Meakin JL. Multiple organ failure syndrome. Arch Surg 1986; 121: 99-103.

5 Shiner M, Nichols VN, Barrish JP, Nichols BL. Pathogenesis of small-intestinal mucosal lessions in chronic diarrhea of infancy: II. An electron microscopic study. F Pediatr Gastroenterol Nutr 1990; 11: 464-80.

6 Gyorgy P. Biochemical aspects of human milk. Am $\mathcal{f}$ Cli Nutr 1971; 24: 970-5.

7 Tanaka R, Mutai M. Improved medium for selective isolation and enumeration of bifidobacterium. Appl Environ Microbiol 1980; 40: 866-9.

8 Gil A, Coval E, Martinez A, Molina JA. Effects of dietary nucleotides on the microbial pattern of feces at term infants. 7 Clin Nutr Gastrocuterol 1986; $1: 34$.

9 Iijima S, Tsujinaka T, Kido Y, Hayashida Y, Ishida $\mathrm{H}$ Homma $\mathrm{T}$, et al. Intravenous administration of nucleosides and a nucleotide mixture diminishes intestinal sides and a nucleotide mixture diminishes intestinal mucosal atrophy induced by total parenteral nut
FPEN F Parenter Enteral Nutr 1993; 17: 265-70.

10 Uauy R, Stringel G, Thomas R, Quan R. Effect of a dietary nucleosides on growth and maturation of the development of the gut in the rat. F Pediatr Gastrocnterol Nutr 1990; 10: $497-503$.

11 Nunez MC, Ayudarte MV, Morales M, Suarez MD, Gil A. Effect of dietary nucleotides on intestinal repair in rats with experimental chronic diarrhoca. FPEN $\mathcal{F}$ Parenter Enteral Nutr 1990; 14: 598-604.

12 Brunser O, Espinoza J, Araya M, Cruchet S, Gil A. Effect of dietary nucleotide supplementation of diarrhoeal disease in infants. Acta Paediatrica 1994; 83: $188-91$.

13 Grimble GK. Dietary nucleotides and gut mucosal defence. Gut 1994; 35 (suppl 1): S46-51.

14 Bueno J, Torres M, Almendros A, Carmona R, Nunez MC, Gil A. Effect of dietary nucleotides on small intestinal repair after diarrhoea. Histological and ultrastructura changes. Gut 1994; 35: 926-33.

15 Kulkarni AD, Rudolph FB, Van Buren CT. The role of dietary sources of nucleotides in immune function: review. 7 Nutr 1994; 124: 1442-6S

16 Rudolph FB, Kulkarni AD, Fanslow WC, Pizzini RP, Van Buren CT. Role of RNA as a dietary source of pyrimidines and purines in immune function. Nutrition 1990; 6: and purin

17 Adjei AA, Ohshiro Y, Yamauchi K, Nakasone Y, Shimada $\mathrm{K}$, Iwanaga $\mathrm{M}$, et al. Intraperitoncal administration induced bacterial translocation in protein-deficient mice. Tohoku 7 Exp Med 1994; 174: 1-10

18 Adjei AA, Yamamoto S. A dietary nucleoside-nucleotide mixture inhibits endotoxin-induced bacterial translocation in mice fed protein-deficient diet. F Nutr 1995 125: $42-8$.

19 Daly JM, Liberman MD, Goldfine J, Shou J, Weintraub F, Rosato EF, et al. Enteral nutrition with supplemental arginine, RNA, and omega-3 fatty acids in patients after operation: immunologic, metabolic, and clinical out-

20 Savaiano DA, Ho CY, Chu V. Metabolism of orally and intravenously administered purines in rats. 7 Nutr 1980 110: $1793-804$

21 Ho CY, Miller KV, Savaiano DA. Absorption and metabolism of orally administered purines in fed and fasted rats. F Nutr 1979; 109: 1377-82.

22 Sonoda T, Tatibana $M$. Metabolic fate of pyrimidines and purines in dietary nucleic acids ingested by mice. Biochem Biophys Acta 1978; 521: 55-56.

23 Garre MA, Boles JM, Youinou PY. Current concepts in immune derangement due to undernutrition. $7 P E N$ Parenter Enteral Nutr 1987; 11: 309-14.

24 Deitch EA, Berg RD. Endotoxin but not malnutrition promotes bacterial translocation of the gut flora in burned mice 7 Trauma $1987 ; 27: 161-6$.

25 Ogoshi S, Iwasa M, Kitagawa S. Effect of total parenteral nutrition with nucleoside-nucleotide mixture on D-galacnutrition with nucleoside-nucleotide mixture on D-galac-
tosamine induced liver injury in rats. $7 P E N \quad \mathcal{F}$ Parenter Euteral Nutr 1988 ; $12: 53-8$.

26 LeLeiko NS, Martin BA, Walsh M, Kazlow P, Rabinowit\% $S$, Sterling K. Tissue-specific gene expression results from a purine and pyrimidine-free diet and 6-mercaptopurine in the rat small intestine and colon. Gastrocnterology 1987 ;

27 Souba WW, Wilmore DW. Postoperative alteration of arteriovenous exchange of amino acids cross the gastrointestinal tract. Surgery 1983; 94: 342-50

28 Savaiano DA, Clifford AJ. Absorption, tissue incorporation and excretion of free-purine bases in rat. Nutrition Report International 1978; 17: 551-6.

29 Savaiano DA, Clifford AJ. Adenine, the precursor of nucleic 
acids in intestinal cells unable to synthesize purines de novo. $\mathcal{f}$ Nutr 1981; 111: 1816-22.

30 Bendich A, Getler H, Brown GB. Studies in metabolism of purines and pyrimidines by isotopic nitrogen. $\mathcal{f}$ Biol Chem purines and pyrimidines by isotopic nitrogen. $\mathrm{f} \mathrm{Biol} \mathrm{Chem}$
$1949 ; 177: 565-70$.

31 Plentl AA, Schoenheimer R. Synthesis of isotope cytosine and study of its metabolism in rats. $\mathcal{F ~ B i o l ~ C h e m ~ 1 9 4 4 ; ~ 1 5 3 : ~}$ 203-17.

32 Burridge $\mathrm{PW}$, Woods RA, Henderson JF. Utilization of dietary nucleic acid purines for nucleotide and nucleic acid synthesis in the mouse. Can $\mathcal{F}$ Biochem 1976; 54: $500-6$.
33 Wilson DW, Wilson HC. Studies on in vitro digestion and absorption of purine ribonucleotides by the intestine. $\mathcal{F}$ Biol Chem 1962; 237: 1643-7.

34 Ogoshi S, Iwasa M, Yonezawa T, Tamiya T. Effect of nucleoside and nucleotide mixture on rats given total

35 Ogoshi S, Iwasa M, Mizobuchi S. Effect of a nucleosidenucleotide mixture on protein metabolism in rats given total parenteral nutrition after $70 \%$ hepatectomy. In: Tanaka T, Okada A, eds. Nutritional support in organ failure. Amsterdam: Elsevier, 1988: 309-17. 